\title{
Effect of cadmium and lead on the membrane potential and photoelectric reaction of Nitellopsis obtusa cells
}

\author{
Renata Kurtyka, Zbigniew Burdach and Waldemar Karcz \\ Department of Plant Physiology, Faculty of Biology and Environmental Protection, University of Silesia, Katowice, Poland
}

\begin{abstract}
The effects of $\mathrm{Cd}$ and $\mathrm{Pb}$ on membrane potential $\left(E_{\mathrm{m}}\right)$ and photoelectric reaction of Nitellopsis obtusa cells were investigated. It was found that $\mathrm{Cd}$ and $\mathrm{Pb}$ at $1.0 \mathrm{mM}$ caused a depolarization of the $E_{\mathrm{m}}$, whereas both metals at lower concentrations changed the $E_{\mathrm{m}}$ in a different way. $\mathrm{Pb}$ at $0.1 \mathrm{mM}$ and $0.01 \mathrm{mM}$ hyperpolarized the $E_{\mathrm{m}}$, whereas $\mathrm{Cd}$ at the same concentrations depolarized and did not change the $E_{\mathrm{m}}$, respectively. In the presence of $0.01 \mathrm{mM} \mathrm{Pb}$, the light-induced hyperpolarization of the $E_{\mathrm{m}}$ was by $18 \%$ higher as compared to the control, whereas at $1.0 \mathrm{mM} \mathrm{Pb}$ it was by $40 \%$ lower. $\mathrm{Pb}$ at $0.1 \mathrm{mM}$ and $\mathrm{Cd}$ at $0.01 \mathrm{mM}$ or $5 \times 0.01 \mathrm{mM}$ did not change the light-induced membrane hyperpolarization. However, in the presence of $\mathrm{Cd}$ at $0.1 \mathrm{mM}$ and $1.0 \mathrm{mM}$ this hyperpolarization was 2 -fold lower or was completely abolished, respectively. These results suggest that at high $\mathrm{Cd}$ and $\mathrm{Pb}$ concentrations both depolarization of the $E_{\mathrm{m}}$ and decrease of light-induced membrane hyperpolarization in Nitellopsis obtusa cells are probably due to inhibition of the plasma membrane $\mathrm{H}^{+}$-ATPase activity, whereas both metals at lower concentrations differ in mechanism of membrane potential changes.
\end{abstract}

Key words: Cadmium - Lead - Membrane potential - Photoelectric reaction - Nitellopsis obtusa

\section{Introduction}

Metals such as cadmium $(\mathrm{Cd})$ and lead $(\mathrm{Pb})$ are very harmful environmental pollutants which are widely known inhibitors of plant metabolism. These metals by binding into specific sites of membranes such as amino, carboxyl, hydroxyl, phosphoryl and sulfhydryl groups have a destructive influence on structure and function of plant membranes (De Filippis 1979). The modification of membrane properties by heavy metals may be caused by changes of their permeability, fluidity, protein and lipid composition (Jones et al. 1987; Stefanov et al. 1993, 1995a,b; Fodor et al. 1995; Ouariti et al. 1997; Llamas et al. 2000; Rucińska and Gwoźdź 2005; Karcz et al. 2009; Miśkiewicz et al. 2010). It is also postulated that plasma membrane may have a role in metal tolerance by preventing or reducing the entry of metals to the cells and it is the first target for ions toxicity, causing changes, among

Correspondence to: Renata Kurtyka, Department of Plant Physiology, Faculty of Biology and Environmental Protection, University of Silesia, ul. Jagiellońska 28, 40032 Katowice, Poland E-mail: renata.kurtyka@us.edu.pl others, in electrical potential (Verkleij and Schat 1990; Sanita' di Toppi and Gabbrielli 1999; Karcz and Kurtyka 2007). Across the plasma membrane there is a membrane potential difference, value of which depends on plant species and type of the cells (Stolarek and Karcz 1987; Elzenga et al. 1995; Lehtonen and Saari 2000). The plasma membrane potential $(E \mathrm{~m})$ consists of two components; the first, the active component, which is generated by an plasma membrane $\mathrm{H}^{+}$ATPase (PM H${ }^{+}$-ATPase) and the second, the passive one, which depends on membrane permeability. The activity of the $\mathrm{PM} \mathrm{H}^{+}$-ATPase is affected among other by temperature (Karcz and Burdach 2007), ion concentrations (Felle 1991) and illumination (Stolarek et al. 1988; Elzenga et al. 1995; Michelet and Boutry 1995).

The dark/light signals cause in plant cells an electrical reaction which depends on plant species and cell type (Karcz 1991; Karcz et al. 1991; Shabala and Newman 1999; Lehtonen and Saari 2000). In Characeae cells a typical reaction on dark/light transition consists of two phases - a rapid transient depolarization of the $E_{\mathrm{m}}$ followed by a slow membrane hyperpolarization (Fujii et al. 1979; Stolarek and Karcz 1987; Stolarek et al. 1988). In turn, light/dark transition causes similar responses but in 
the opposite direction (Shimmen et al. 1994). It was previously shown in experiments performed with Elodea densa cells and Nicotiana tabacum mesophyll protoplasts that light-induced electrogenic $\mathrm{H}^{+}$extrusion (membrane hyperpolarization) is associated with increased of $\mathrm{K}^{+}$uptake and alkalinization of cell sap, which are the symptoms of an increase of $\mathrm{PM} \mathrm{H}^{+}$-ATPase activity (Marrè et al. 1989; Blom-Zandstra et al. 1997). Among the different ions which are responsible for electrical reaction to light the most likely candidate for membrane depolarization is $\mathrm{Ca}^{2+}$, whereas $\mathrm{K}^{+}$seems to function as the equilibrium ion, moving passively across the plasma membrane to compensate for light-induced charge movement of $\mathrm{Cl}^{-}$or $\mathrm{H}^{+}$(Shabala and Newman 1999). It has also been shown that the effects of light on membrane potential changes are suppressed by treatment the cells with the photosynthetic 3-(3'-4'-dichlorophenyl)1,1-dimethylurea (DCMU), and $\mathrm{PM} \mathrm{H}^{+}$-ATPase inhibitors (Marrè et al. 1989; Karcz 1991; Okazaki et al. 1994; Harada et al. 2002). It was also proposed that in photosynthetically active cells the light signal from chloroplasts to the $\mathrm{PM} \mathrm{H}^{+}$-ATPase is carried by electrons (Elzenga and Prins 1989), and PSII system (Köhler et al. 1985).

The main goal of the present study was to compare the effects of $\mathrm{Cd}$ and $\mathrm{Pb}$ ions on the membrane potential and photoelectric reaction in internodal cells of Nitellopsis obtusa. The internodal cells have proved to be the most suitable material for analyzing the electrical characteristics of membranes of plant cells because of their large cell size and diameter (Shimmen et al. 1994; Tazawa and Shimmen 2001).

\section{Materials and Methods}

\section{Plant material and growth conditions}

The experiments were carried out with internodal cells of giant algae Nitellopsis obtusa (Characeae), which were grown in an aquarium in the natural pond water at $25^{\circ} \mathrm{C}$, under fixed light cycle of $16 \mathrm{~h}$ light and $8 \mathrm{~h}$ dark. Before the experiments the cells were incubated within $2 \mathrm{~h}$ in basic solution (APW - artificial pond water) containing: $1.0 \mathrm{mM}$ $\mathrm{KCl}, 0.1 \mathrm{mM} \mathrm{NaCl}, 0.1 \mathrm{mM} \mathrm{CaCl}_{2} ; \mathrm{pH}$ of the medium was 5.8-6.0. After this period one of them was transferred into a perfusion plexiglass chamber which was mounted on a vertically placed microscope stage.

\section{Measurement of membrane potential}

The standard electrophysiological technique was used for membrane potential measurements, as previously described by Stolarek and Karcz (1987) and Karcz and Burdach (2002). The $E_{\mathrm{m}}$ differences were measured by recording the voltage between a $3 \mathrm{M} \mathrm{KCl-filled} \mathrm{glass} \mathrm{micropipette} \mathrm{inserted}$ into the vacuole and a reference electrode in the external medium. The microelectrodes were inserted into Nitellopsis obtusa cells under microscope by using of micromanipulator (Hugo Sachs Electronik, March-Hugstteten, Germany). Micropipettes were pulled on a vertical pipette puller (model L/M-3P-A, List-Medical, Germany) from borosilicate glass capillaries (type 1B150F-3, World Precision Instruments, USA). Tip diameters were less than $1 \mu \mathrm{m}$. After stabilization of $E_{\mathrm{m}}(<20 \mathrm{~min})$ the external medium was changed for a new one, at the same salt composition, containing additionally $\mathrm{CdCl}_{2}$ or $\mathrm{PbCl}_{2}$ at the final concentration $1.0,0.1$ and 0.01 $\mathrm{mM}$. Medium changes were done by means of peristaltic pump (type Peri-Star PRO, World Precision Instruments, USA). The membrane potential in the presence of metals was measured continuously within $45 \mathrm{~min}$.

The next part of our experiments concerned with the effects of $\mathrm{Cd}(1.0,0.1,5 \times 0.01$ and $0.01 \mathrm{mM})$ and $\mathrm{Pb}(1.0,0.1$ and $0.01 \mathrm{mM}$ ) on light-induced electrical reaction (photoelectric reaction) in Nitellopsis obtusa cells. In this case, the visible light $\left(70 \mathrm{~W}^{-2}\right)$ from a $100 \mathrm{~W}$ halogen bulb (model $\mathrm{ZH}$ 100, PZO Warsaw) was switched on twice; first, for 30 min after stabilization of $E_{\mathrm{m}}$ in the dark in control medium and second, after $30 \mathrm{~min}$ the treatment Nitellopsis obtusa cells with cadmium or lead.

\section{Statistical analysis}

Data were analyzed by using the computer software Statistica by StatSoft Inc. (data analysis software system), version 8.0. (www.statsoft.com). Differences between individual treatments and control were analyzed using one-way ANOVA and LSD test. Statistical significance was $p<0.05$.

\section{Results}

The changes in electric potential differences between the vacuole and the medium in cells of Nitellopsis obtusa incubated in the presence of $\mathrm{Cd}$ and $\mathrm{Pb}$ were determined. The $E_{\mathrm{m}}$ of these cells, before being changed in response to $\mathrm{Cd}$ and $\mathrm{Pb}$ was $-151.4 \pm 6.9 \mathrm{mV}$ (means $\pm \mathrm{SE}, n=8$ ) and $-156.5 \pm 3.8$ $\mathrm{mV}$ (means $\pm \mathrm{SE}, n=8$ ), respectively. The electric potential measurements in the cells of Nitellopsis obtusa clearly showed a dependence of their $E_{\mathrm{m}}$ on $\mathrm{Cd}$ and $\mathrm{Pb}$ concentrations (Figs. $1,2)$. Both metals, at $1.0 \mathrm{mM}$ caused an immediate depolarization of $E_{\mathrm{m}}$, value of which was significantly higher for Cd (depolarization by $81.9 \pm 3.9 \mathrm{mV}, n=8$ ) than for $\mathrm{Pb}$ (depolarization by $40.6 \pm 1.9 \mathrm{mV}, n=8$ ) (Figs. 1,2 ). Treatment of internodal cells with $\mathrm{Cd}$ at $0.1 \mathrm{mM}$ caused a depolarization of $E_{\mathrm{m}}$ by $57.9 \pm 2.4 \mathrm{mV}$ (means $\pm \mathrm{SE}, n=8$ ) whereas $\mathrm{Cd}$ at $0.01 \mathrm{mM}$ did not change the $E_{\mathrm{m}}$ (Fig. 1 ). $\mathrm{Pb}$, in contrast to $\mathrm{Cd}$, applied at $0.01 \mathrm{mM}$ and $0.1 \mathrm{mM}$ brought about membrane hyperpolarization by $19.8 \pm 0.9 \mathrm{mV}$ (means $\pm \mathrm{SE}, n=8$ ) and $15.6 \pm 0.8 \mathrm{mV}$ (means $\pm \mathrm{SE}, n=8$ ), respectively (Fig. 2). 


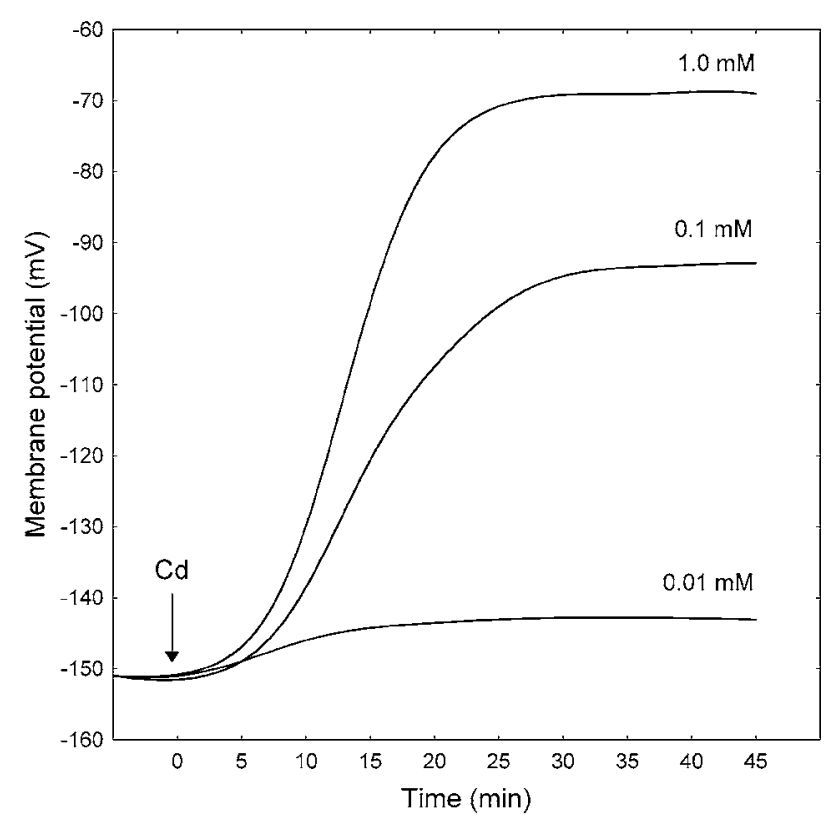

Figure 1. Effect of Cd $(1.0,0.1,0.01 \mathrm{mM})$ on the membrane potential $\left(E_{\mathrm{m}}\right)$ of Nitellopsis obtusa cells. (At time 0 , the control medium was changed for a new one, at the same salt composition, containing in addition Cd). Standard error (SE) did not exceed 5\%, $n=8$.

The kinetics of light-induced membrane potential changes in Nitellopsis obtusa cells incubated in the presence of Cd or $\mathrm{Pb}$ was also investigated. We have showed that the exposure of the cells (medium without metal) to visible light caused a transient depolarization of $E_{\mathrm{m}}$ (which was usually finished within $2 \mathrm{~min}$ ) after which a delayed hyperpolarization of $E \mathrm{~m}$ by $65.7 \pm 2.9 \mathrm{mV}$ (means $\pm \mathrm{SE}, n=8$ ) was observed (Fig. $3 \mathrm{~A}$ ).

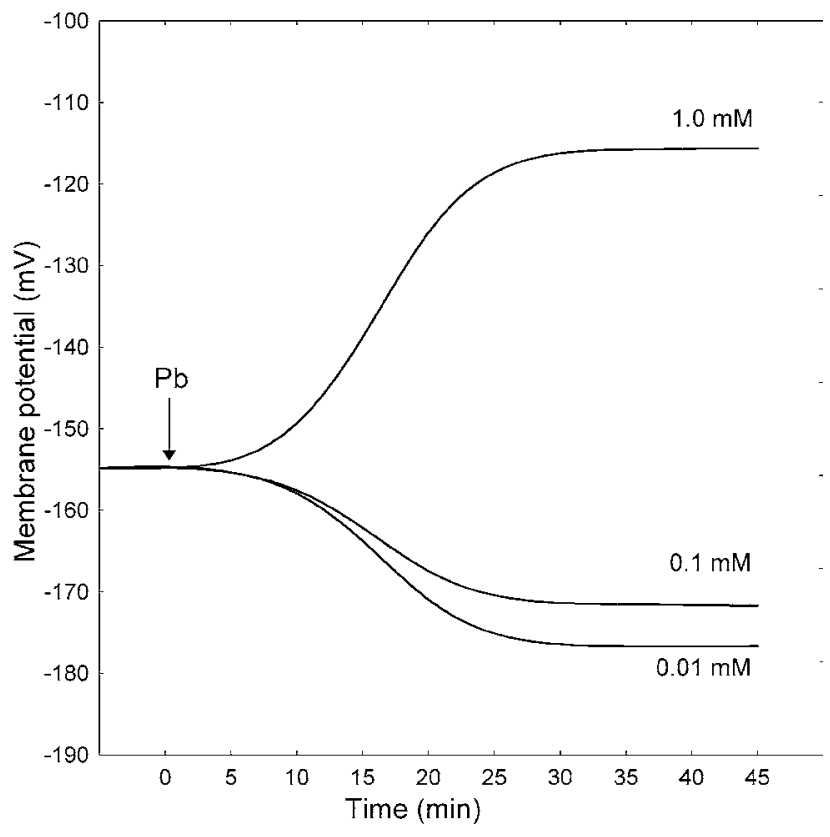

Figure 2. Effect of $\mathrm{Pb}(1.0,0.1,0.01 \mathrm{mM})$ on the membrane potential $\left(E_{\mathrm{m}}\right)$ of Nitellopsis obtusa cells. (At time 0 , the control medium was changed for a new one, at the same salt composition, containing in addition $\mathrm{Pb}$ ). Standard error (SE) did not exceed 5\%, $n=8$.

The same cells treated again with light (after period of 60 min in the dark) showed practically identical kinetics of the membrane potential changes as in the first case (Fig. 3A, Tab. 1). The data presented here show that the photoelectric reaction (light-induced membrane hyperpolarization) of Nitellopsis obtusa cells was changed in the presence of $\mathrm{Cd}$ or $\mathrm{Pb}$ (Fig. 3 and Tab. 1). It was found that at $0.01 \mathrm{mM} \mathrm{Pb}$ the

Table 1. Effect of $\mathrm{Cd}$ and $\mathrm{Pb}$ ions on the photoelectrical reaction of Nitellopsis obtusa cells. The visible light was switch on twice; first, for $30 \mathrm{~min}$ after stabilization of $\mathrm{E}_{\mathrm{m}}$ in the dark in control medium and second, after $30 \mathrm{~min}$ the treatment Nitellopsis obtusa cells with cadmium or lead

\begin{tabular}{|c|c|c|c|c|c|c|}
\hline \multirow[b]{2}{*}{ Treatment } & & \multicolumn{5}{|c|}{ Membrane potential, $E_{\mathrm{m}}(\mathrm{mV})$} \\
\hline & & $\begin{array}{l}\text { after stabilization in } \\
\text { the control medium }\end{array}$ & $\begin{array}{l}30 \text { min after } \\
\text { light-on }\end{array}$ & $\begin{array}{l}60 \text { min after } \\
\text { light-off }\end{array}$ & $\begin{array}{c}30 \text { min after treatment } \\
\text { with metal or with control } \\
\text { solution }\end{array}$ & $\begin{array}{l}30 \text { min after } \\
\text { light-on }\end{array}$ \\
\hline \multirow[t]{2}{*}{ Control } & & $-153.7 \pm 7.8^{\text {fghi }}$ & $-219.4 \pm 5.5^{\mathrm{b}}$ & $-166.0 \pm 9.0^{\mathrm{def}}$ & $-162.2 \pm 7.5^{\operatorname{deg}}$ & $-217.0 \pm 8.4^{b}$ \\
\hline & 0.01 & \multirow{4}{*}{$-150.2 \pm 3.3^{\text {fghi }}$} & \multirow{4}{*}{$-221.1 \pm 4.8^{b}$} & \multirow{4}{*}{$-160.9 \pm 4.3^{\mathrm{eh}}$} & $-155.0 \pm 6.4^{\text {ehi }}$ & $-222.3 \pm 6.2^{b}$ \\
\hline \multirow{3}{*}{$\begin{array}{l}\mathrm{Cd} \\
(\mathrm{mM})\end{array}$} & 0.05 & & & & $-139.6 \pm 8.9^{\mathrm{ij}}$ & $-188.3 \pm 6.9^{c}$ \\
\hline & 0.1 & & & & $-93.9 \pm 7.8^{\mathrm{kl}}$ & $-125.9 \pm 6.1^{j}$ \\
\hline & 1.0 & & & & $-72.1 \pm 6.2^{\mathrm{m}}$ & $-75.7 \pm 5.8^{1 \mathrm{~lm}}$ \\
\hline \multirow{3}{*}{$\begin{array}{l}\mathrm{Pb} \\
(\mathrm{mM})\end{array}$} & 0.01 & \multirow{3}{*}{$-155.1 \pm 10.4^{\mathrm{ehi}}$} & \multirow{3}{*}{$-221.3 \pm 3.4^{b}$} & \multirow{3}{*}{$-58.2 \pm 9.9^{\mathrm{ehi}}$} & $-178.1 \pm 6.2^{\mathrm{cd}}$ & $-256.7 \pm 8.2^{\mathrm{a}}$ \\
\hline & 0.1 & & & & $-174.9 \pm 8.4^{\mathrm{ce}}$ & $-235.9 \pm 5.6^{\mathrm{b}}$ \\
\hline & 1.0 & & & & $-104.9 \pm 5.2^{\mathrm{k}}$ & $-132.3 \pm 8.5^{\mathrm{j}}$ \\
\hline
\end{tabular}

The data are means of at least eight independent experiments. Error indicate \pm SE. Means followed by the same letter are not significantly different from each other using the LSD-test $(p<0.05)$. 
light-induced hyperpolarization of the $E_{\mathrm{m}}$ was by $12.4 \pm 0.9$ $\mathrm{mV}$ (means $\pm \mathrm{SE}, n=8$ ) higher as compared to the control, whereas $\mathrm{Cd}$ at the same concentration as well as $\mathrm{Pb}$ at $0.1 \mathrm{mM}$ did not change ligt-induced membrane hyperpolarization. However, Cd at $5 \times 0.01 \mathrm{mM}$ decreased this hyperpolarization by $22 \mathrm{mV}$. In the presence of $0.1 \mathrm{mM} \mathrm{Cd}$ and $1.0 \mathrm{mM} \mathrm{Pb}$ the light-induced hyperpolarization of $E_{\mathrm{m}}$ was 2-fold smaller as compared to the control. Interestingly, $\mathrm{Cd}$ at the highest concentration $(1.0 \mathrm{mM})$ totally abolished the photoelectric reaction of Nitellopsis obtusa cells.

\section{Discussion}

The data presented in this paper show that $\mathrm{Cd}$ and $\mathrm{Pb}$ at $1.0 \mathrm{mM}$ caused a depolarization of the $E_{\mathrm{m}}$, whereas both metals at lower concentrations changed the $E_{\mathrm{m}}$ in a different way. $\mathrm{Pb}$ at $0.1 \mathrm{mM}$ and $0.01 \mathrm{mM}$ hyperpolarized the $E_{\mathrm{m}}$, whereas $\mathrm{Cd}$ at the same concentrations depolarized and did not change the $E_{\mathrm{m}}$, respectively (Figs. 1,2). Similar results were also obtained in our previous study (Karcz and Kurtyka 2007) in experiments performed with parenchymal cells of maize coleoptile segments which, incubated at $0.1 \mathrm{mM} \mathrm{Cd}$, were depolarized by approx. $60 \mathrm{mV}$. We have suggested that the effect of $\mathrm{Cd}$ on the membrane potential of parenchymal cells might be, at least in part, caused via reduced $\mathrm{PM} \mathrm{H} \mathrm{H}^{+}$-ATPase activity. Effect of $\mathrm{Cd}$ on both membrane-bound ATPase activity and $\mathrm{K}^{+}$uptake in Beta vulgaris L. roots has been studied by Lindberg and Wingstrand (1985). They showed that in vitro application of Cd inhibited the $\mathrm{PM} \mathrm{H}^{+}$-ATPase activity and $\mathrm{K}^{+}$uptake. In turn, Ros et al. (1992) reported that Cd modified the $\mathrm{PM} \mathrm{H} \mathrm{H}^{+}$-ATPase activity from rice (Oryza sativa L.), but this effect depended on the performed assay (in vivo or in vitro). The results reported by Perfus-Barbeoch et al. (2002) should also be mentioned. These authors obtained that $\mathrm{Cd}^{2+}$ mimics $\mathrm{Ca}^{2+}$ and enteres Vicia faba guard cells through voltage-dependent $\mathrm{Ca}^{2+}$ channels, whereas $\mathrm{K}^{+}$ channels were insensitive to external $\mathrm{Cd}^{2+}$ application. In turn, Lindberg et al. (2004) showed that cadmium uptake into the cytosol of wheat protoplasts partly takes place by channels permeable to calcium and potassium, and is dependent on membrane potential. Taking into account that cadmium is more easily taken up into the cells than $\mathrm{Pb}$ (Pahlsson 1989) it could be suggested that $\mathrm{Pb}$ only at high concentration $(1.0 \mathrm{mM})$ caused a depolarization, while $\mathrm{Cd}$ ions do this at lower concentrations $(\mathrm{Cd}$ at $0.1 \mathrm{mM}$ and to some extent $0.01 \mathrm{mM} \mathrm{Cd}$ ). The hyperpolarization of the $E_{\mathrm{m}}$ in the presence of lead acetate was also found by Morse and Spanswick (1984) in cells of Nitella translucens and was ascribed by the authors to block $\mathrm{K}^{+}$channels. Morse and Spanswick (1984), in contrast to our data, observed hyperpolarization of the $E_{\mathrm{m}}$ in the presence of a very high $\mathrm{Pb}$ concentration ( $5 \mathrm{mM})$. This discrepancy between electrical responses of Nitellopsis obtusa and Nitella translucens to $\mathrm{Pb}$ probably results from different lead salts used (Sharma and Chopra 1987; Małkowski et al. 1996). The effect of Cd and $\mathrm{Pb}$ on the $E_{\mathrm{m}}$ of Nitellopsis obtusa cells observed here
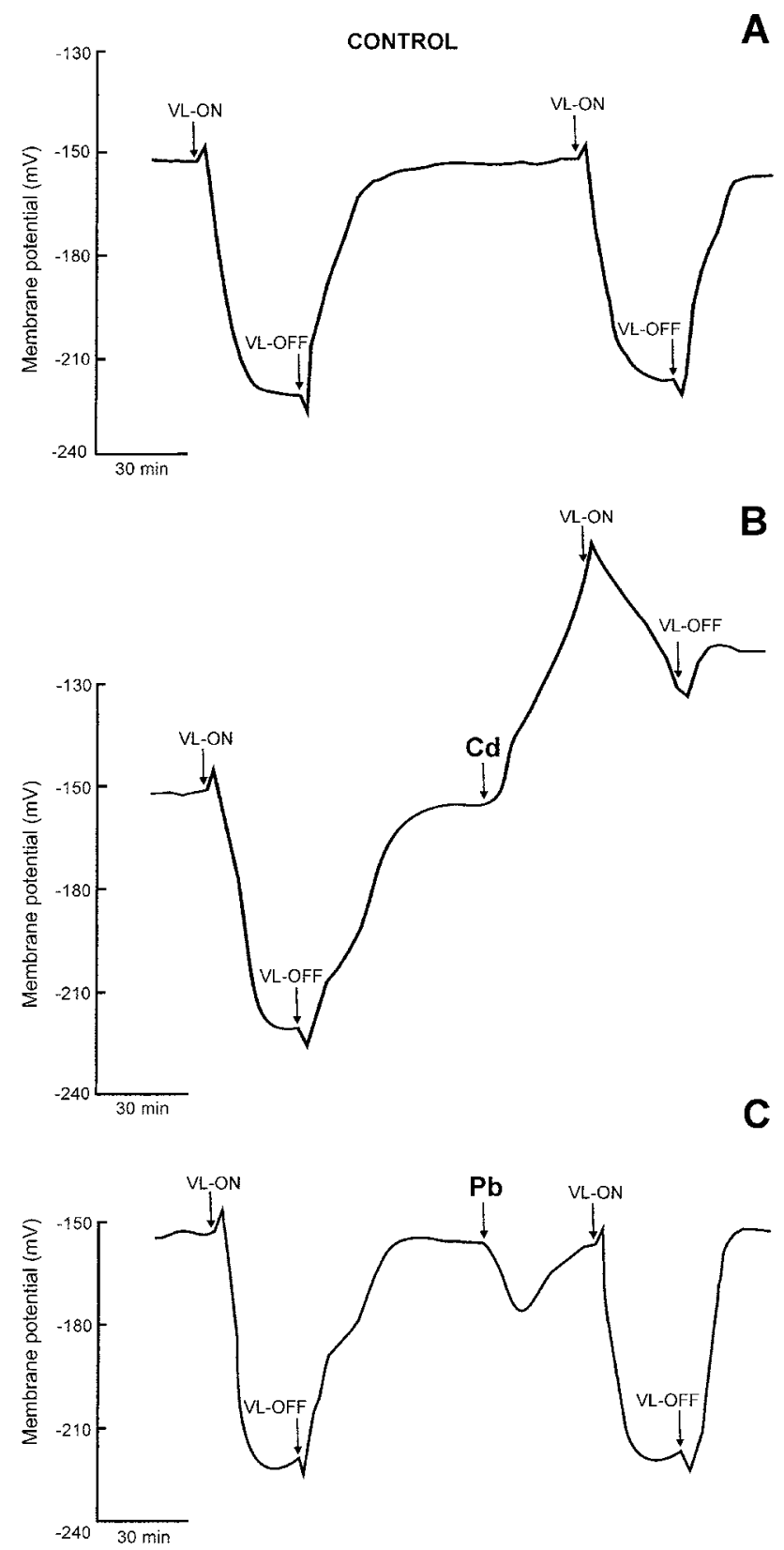

Figure 3. Responses of Nitellopsis obtusa cells (representative traces) to illumination (VL-ON) and darkening (VL-OFF) A. Control (exposure of the cells to visible light caused a transient, small depolarization of the membrane potential after which a delayed hyperpolarization of $E_{m}$ was observed). B. Treatment with $0.1 \mathrm{mM}$ $\mathrm{Cd}$ ions. C. Treatment with $0.1 \mathrm{mM} \mathrm{Pb}$ ions. Adequate mean values are indicated in Table 1. 
may be caused by both the decrease of the $\mathrm{PM} \mathrm{H}^{+}$-ATPase activity and the changes in plasma membrane permeability, especially for $\mathrm{Ca}^{2+}$ and $\mathrm{K}^{+}$ions (Morse and Spanswick 1984; Małkowski et al. 2005; Karcz and Kurtyka 2007). This suggestion is supported by our previous study (Małkowski et al. 2005), in which we showed that the Cd ions at high concentration $(1.0 \mathrm{mM})$ decreased the content of $\mathrm{Ca}^{2+}$ in root cells of Zea mays L., and also by other authors who showed that $\mathrm{Cd}$, but not $\mathrm{Pb}$, induced a depolarization of the membrane potential (Llamas et al. 2000; Pavlovkin et al. 2006; Karcz and Kurtyka 2007) which resulted from decreased $\mathrm{PM} \mathrm{H}^{+}$-ATPase activity (Kennedy and Gonsalvez 1987, 1989; Burzyński and Buczek 1994; Fodor et al. 1995; Astolfi et al. 2003).

It has already been demonstrated that the membrane potential of Characean cells is very sensitive to light/dark and dark/light transitions (for review see Shimmen et al. 1994). In photosynthetic plant cells, the light can rapidly modulate the $\mathrm{PM} \mathrm{H}^{+}$-ATPase activity and voltage-dependent ion channels. The typical light-induced reaction consists of a quick initial depolarization of the $E_{\mathrm{m}}$ (Spalding and Cosgrove 1992; Elzenga et al. 1995; Shabala and Newman 1999; Stahlberg and van Volkenburgh 1999), followed by a slow membrane repolarization which very often resulted in plasma membrane hyperpolarization (Karcz 1991; Spalding and Cosgrove 1992; Blom-Zandstra et al. 1997; Stahlberg and van Volkenburgh 1999). Similar to the above cited authors we have showed that the exposure of the Nitellopsis obtusa cells to visible light caused a transient depolarization of $E_{\mathrm{m}}$ (which was usually finished within $2 \mathrm{~min}$ ) after which a delayed hyperpolarization of $E_{\mathrm{m}}$ by $65.7 \pm 2.9 \mathrm{mV}$ (means \pm SE, $n=8$ ) was observed (Fig. $3 \mathrm{~A}$, Tab. 1). Several authors (Ermolayeva et al. 1996; Johannes et al. 1997; Shabala and Newman 1999) have suggested that $\mathrm{Ca}^{2+}$ could be a potent depolarizing ion which enters cytosol can stimulate the PM $\mathrm{H}^{+}$-ATPase activity, resulting in an increase of $\mathrm{H}^{+}$efflux (Shabala and Newman 1999). It has also been previously shown (Okazaki et al. 1994) that $\mathrm{H}^{+}$ions apart from being extruded out of the cells are also taken up into the organelles such as vacuoles and chloroplasts.

The data presented in this paper clearly show that the $\mathrm{Cd}^{2+}$ ions are much more effective, than $\mathrm{Pb}^{2+}$ ions, in altering the light-induced membrane hyperpolarization (Fig. 3 and Tab. 1). This effect is probably connected with the fact that $\mathrm{Cd}^{2+}$ ions, which are more easily taken up by cells than $\mathrm{Pb}$, alter the membrane permeability, especially for $\mathrm{Ca}^{2+}$ and $\mathrm{K}^{+}$ions. Furthermore, it is also possible that the inhibitory effect of Cd on photoelectric reaction is related to inhibition of photosynthesis by this metal (Siedlecka and Krupa 1996; Tukaj et al. 2007).

Taken together, these results suggest that at high $\mathrm{Cd}$ and $\mathrm{Pb}$ concentrations both depolarization of the $E_{\mathrm{m}}$ and decrease of light-induced membrane hyperpolarization in
Nitellopsis obtusa cells are probably due to inhibition of the $\mathrm{PM} \mathrm{H}^{+}$-ATPase activity, whereas both metals at lower concentrations differ in mechanism of membrane potential changes.

\section{References}

Astolfi S., Zuchi S., Chiani A., Passera C. (2003): In vivo and in vitro effects of cadmium on $\mathrm{H}^{+}$ATPase activity of plasma membrane vesicles from oat (Avena sativa L.) roots. J. Plant Physiol. 160, 387-393 doi:10.1078/0176-1617-00832

Blom-Zandstra M., Koot H., van Hattum J., Vogelzang S.A. (1997): Transient light-induced changes in ion channel and proton pump activities in the plasma membrane of tobacco mesophyll protoplasts. J. Exp. Bot. 48, 1623-1630

Burzyński M., Buczek J. (1994): The influence of Cd, Cu, Pb and Ni on $\mathrm{NO}_{3}-$ uptake by cucumber seedlings. II. In vitro and in vivo effect of $\mathrm{Cd}, \mathrm{Cu}, \mathrm{Pb}$ and $\mathrm{Ni}$ on the plasmalemma ATPase and oxidoreductase from cucumber seedling roots. Acta Physiol. Plant. 16, 297-302

De Filippis L. F. (1979): The effect of heavy metal compounds on the permeability of Chlorella cells. Z. Pflanzenphysiol. 92, 39-49

Elzenga J. T. M., Prins H. B. A. (1989): Light-induced polar pH changes in leaves of Elodea canadensis. II. Effects of ferricyanide: Evidence for modulation by the redox state of the cytoplasm. Plant Physiol. 91, 68-72 doi:10.1104/pp.91.1.68

Elzenga J. T. M., Prins H. B. A., van Volkenburgh E. (1995): Light-induced membrane potential changes of epidermal and mesophyll cells in growing leaves of Pisum sativum. Planta 197, 127-134 doi:10.1007/BF00239948

Ermolayeva E., Hohmeyer H., Johannes E., Sanders D. (1996): Calcium-dependent membrane depolarization activated by phytochrome in the moss Physcomitrella patens. Planta 199, 352-358

doi:10.1007/BF00195726

Felle H. H. (1991): The role of the plasma membrane proton pump in short-term $\mathrm{pH}$ regulation in the aquatic liverwort Riccia fluitans L. J. Exp. Bot. 42, 645-652 doi:10.1093/jxb/42.5.645

Fodor E., Szabo-Nagy A., Erdei L. (1995): The effect of cadmium on the fluidity and $\mathrm{H}^{+}$-ATPase activity of plasma membrane from sunflower and wheat roots. J. Plant Physiol. 147, 87-92

Fujii S., Shimmen T., Tazawa M. (1979): Effect of intracellular pH on the light-induced potential change and electrogenic activity in tonoplast-free cells of Chara australis. Plant Cell Physiol. 20, 1315-1328

Harada Y., Okazaki S., Takagi S. (2002): Photosynthetic control of the plasma membrane $\mathrm{H}^{+}$-ATPase in Vallisneria leaves. I. Regulation of activity during light-induced membrane hyperpolarization. Planta 214, 863-869 doi:10.1007/s00425-001-0689-x

Johannes E., Ermolayeva E., Sanders D. (1997): Red light-induced membrane potential transients in the moss Physcomitrella 
patens: ion channel interaction in phytochrome signalling. J. Exp. Bot. 48, 599-608 doi:10.1093/jxb/48.Special_Issue.599

Jones G. J., Nichols P. B., Johns R. S., Smith J. B. (1987): The effect of mercury and cadmium on the fatty acid and sterol composition of the marine diatom Asterionella glacialis. Phytochem. 26, 1343-1348 doi:10.1016/S0031-9422(00)81809-9

Karcz W. (1991): Effects of visible light and fusicoccin on membrane potential and $\mathrm{pH}$ of the incubation medium of Sagittaria leaf cells. Acta Biol. Sil. 17, 16-22

Karcz W., Stolarek J., Kurtyka R. (1991): Photoelectrical reactions in Cucurbita pepo L. modified by action potentials induced by electrical and thermal stimuli. Acta Biol. Sil. 17, 24-33

Karcz W., Burdach Z. (2002): A comparison of the effects of IAA and 4-Cl-IAA on growth, proton secretion and membrane potential in maize coleoptile segments. J. Exp. Bot. 53, 1089-1098 doi:10.1093/jexbot/53.371.1089

Karcz W., Burdach Z. (2007): Effects of temperature on growth, proton extrusion and membrane potential in maize (Zea mays L) coleoptile segments. Plant Growth Regul. 52, 141-150 doi:10.1007/s10725-007-9184-0

Karcz W., Kurtyka R. (2007): Effect of cadmium on growth, proton extrusion and membrane potential in maize coleoptile segments. Biol. Plant. 51, 713-719 doi:10.1007/s10535-007-0147-0

Karcz W., Trela Z., Burdach Z., Przestalski S. (2009): Effect of trimethyllead chloride $\left(\mathrm{Met}_{3} \mathrm{PbCl}\right)$ on SV channels and volume changes in the red beet vacuoles. Acta Biol. Crac. Ser. Bot. 51 (Suppl. 2), 105-106

Kennedy C. D., Gonsalves F. A. N. (1987): The action of divalent zinc, cadmium, mercury, copper and lead on the trans-root potential and $\mathrm{H}^{+}$efflux of excised roots. J. Exp. Bot. 38, $800-817$ doi: $10.1093 / \mathrm{jxb} / 38.5 .800$

Kennedy C. D., Gonsalves F. A. N. (1989): The action of divalent $\mathrm{Zn}, \mathrm{Cd}, \mathrm{Hg}, \mathrm{Cu}$ and $\mathrm{Pb}$ ions on the ATPase activity of a plasma membrane fraction isolated from roots of Zea mays. Plant Soil 117, $167-175$ doi:10.1007/BF02220709

Köhler K., Steigner W., Simonis W., Urbach W. (1985): Potassium channels in Eremosphaera viridis. I. Influence of cations and $\mathrm{pH}$ on resting membrane potential and on an action-potential-like response. Planta 166, 490-499

Lehtonen J., Saari J. (2000): Illumination does not affect the membrane potential or the plasma membrane $\mathrm{H}^{+}$-ATPase activity in Micrasterias. Physiol. Plant. 110, 436-442 doi:10.1111/j.1399-3054.2000.1100402.x

Lindberg S., Wingstrand G. (1985): Mechanism of $\mathrm{Cd}^{+2}$ inhibition of $\left(\mathrm{K}^{+}+\mathrm{Mg}^{+2}\right)$ ATPase activity and $\mathrm{K}^{+}\left({ }^{86} \mathrm{Rb}^{+}\right)$uptake in young roots of sugar beet (Beta vulgaris). Physiol. Plant. 63, 181-186 doi:10.1111/j.1399-3054.1985.tb01900.x

Lindberg S., Landberg T., Greger M. (2004): A new method to detect cadmium uptake in protoplasts. Planta 219, 526-532 doi:10.1007/s00425-004-1256-Z

Llamas A., Ullrich C. I., Sanz A. (2000): $\mathrm{Cd}^{2+}$ effects on transmembrane electrical potential difference, respiration and membrane permeability of rice (Oryza sativa L.) roots. Plant Soil 219, 21-28

doi:10.1023/A:1004753521646

Małkowski E., Stolarek J., Karcz W. (1996): Toxic effect of $\mathrm{Pb}^{2+}$ ions on extension growth of cereal plants. Pol. J. Environ. Stud. 5, 41-45

Małkowski E., Kurtyka R., Kita A., Karcz W. (2005): Accumulation of $\mathrm{Pb}$ and $\mathrm{Cd}$ and its effect on $\mathrm{Ca}$ distribution in maize seedlings (Zea mays L.). Pol. J. Environ. Stud. 14, 203-207

Marrè M. T., Albergoni F. G., Moroni A., Marrè E. (1989): Light induced activation of electrogenic $\mathrm{H}^{+}$extrusion and $\mathrm{K}^{+}$uptake in Elodea densa depends on photosynthesis and is mediated by the plasma membrane $\mathrm{H}^{+}$-ATPase. J. Exp. Bot. 40, 343-352 doi:10.1093/jxb/40.3.343

Michelet B., Boutry M. (1995): Update on $\mathrm{H}^{+}$-ATPase: The plasma membrane $\mathrm{H}^{+}$-ATPase: A highly regulated enzyme with multiple physiological functions. Plant Physiol. 108, $1-6$

Miśkiewicz J., Trela Z., Przestalski S., Karcz W. (2010): Superstatistics analysis of the ion current distribution function: $\mathrm{Met}_{3} \mathrm{PbCl}$ influence study. Eur. Biophys. J. 39, 1397-1406 doi:10.1007/s00249-010-0594-y

Morse M. J., Spanswick R. M. (1984): Effect of lead acetate on the $\mathrm{K}^{+}$influx in Nitella translucens. In: Membrane Transport in Plants. (Eds. W. J. Cram, K. Janáček, R. Rybová and K. Sigler), pp. 336-337, Academia, Prague

Okazaki Y., Tazawa M., Iwasaki N. (1994): Light-induced changes in cytosolic $\mathrm{pH}$ in leaf cells of Egeria densa: measurements with $\mathrm{pH}$-sensitive microelectrodes. Plant Cell Physiol. 35, 943-950

Ouariti O., Boussama N., Zarrouk M., Cherif A., Ghorbal M. H. (1997): Cadmium- and copper-induced changes in tomato membrane lipids. Phytochem. 45, 1343-1350 doi:10.1016/S0031-9422(97)00159-3

Pahlsson A. M. B. (1989): Toxicity of heavy metals ( $\mathrm{Zn}, \mathrm{Cu}, \mathrm{Cd}$, $\mathrm{Pb}$ ) to vascular plants: literature review. Water Air Soil Pollut. 47, 287-319 doi:10.1007/BF00279329

Pavlovkin J., Luxová M., Mistríková I., Mistrík I. (2006): Shortand long-term effects of cadmium on transmembrane electric potential $\left(\mathrm{E}_{\mathrm{m}}\right)$ in maize roots. Biol. (Bratisl.) 61, 109-114 doi:10.2478/s11756-006-0016-x

Perfus-Barbeoch L., Leonhardt N., Vavasseur A., Forestier C. (2002): Heavy metal toxicity: cadmium permeates through calcium channels and disturbs the plant water status. Plant J. 32, 539-548 doi:10.1046/j.1365-313X.2002.01442.x

Ros R., Morales A., Segura J., Picazo I. (1992) In vivo and in vitro effects of nickel and cadmium on the plasmalemma ATPase from rice (Oryza sativa L.) shoots and roots. Plant Sci. 83, 1-6 doi:10.1016/0168-9452(92)90055-Q

Rucińska R., Gwóźdź E. A. (2005): Influence of lead on membrane permeability and lipoxygenase activity in lupine roots. Biol. Plant. 49, 617-619 doi:10.1007/s10535-005-0059-9

Sanita ' di Toppi L., Gabbrielli R. (1999): Response to cadmium in higher plants. Environ. Exp. Bot. 41, 105-130 doi:10.1016/S0098-8472(98)00058-6 
Shabala S., Newman I. (1999): Light-induced changes in hydrogen, calcium, potassium, and chloride ion fluxes and concentrations from the mesophyll and epidermal tissues of bean leaves. Understanding the ionic basis of light-induced bioelectrogenesis. Plant Physiol. 119, 1115-1124 doi:10.1104/pp.119.3.1115

Sharma S. D., Chopra R. N. (1987): Effect of lead nitrate and lead acetate on growth of the moss Semibarbula onentalis (Web.) Wijk. et Marg. grown in vitro. J. Plant Physiol. 28, 243-249

Shimmen T., Mimura T., Kikuyama M., Tazawa M. (1994): Characean cells as a tool for studying electrophysiological characteristics of plant cells. Cell Struct. Funct. 19, 263-278 doi:10.1247/csf.19.263

Siedlecka A., Krupa Z. (1996): Interaction between cadmium and iron and its effects on photosynthetic capacity of primary leaves of Phaseolus vulgaris. Plant Physiol. Biochem. 34, 833-841

Spalding E. P., Cosgrove D. J. (1992): Mechanism of blue-lightinduced membrane depolarization in etiolated cucumber hypocotyls. Planta 188, 199-205 doi:10.1007/BF00216814

Stahlberg R., van Volkenburgh E. (1999): The effect of light on membrane potential, apoplastic $\mathrm{pH}$ and cell expansion in leaves of Pisum sativum L. var. Argenteum. Planta 208, 188-195 doi:10.1007/s004250050549

Stefanov K., Popova I., Kamburova E., Pancheva T., Kimenov G., Kuleva L., Popov S. (1993): Lipid and sterol changes in Zea mays caused by lead ions. Phytochem. 33, 47-51 doi:10.1016/0031-9422(93)85394-7
Stefanov K., Seizova K., Popova I., Petkov V., Kimenov G., Popov S. (1995a): Effect of lead ions on the phospholipid composition in leaves of Zea mays and Phaseolus vulgaris. J. Plant Physiol. 137, 243-246

Stefanov K. L., Pandev S. D., Seizova K. A., Tyankova L. A., Popov S. S. (1995b): Effect of lead on the lipid metabolism in spinach leaves and thylakoid membranes. Biol. Plant. 37, 251-256 doi:10.1007/BF02913222

Stolarek J., Karcz W. (1987): Effects of UV-C radiation on membrane potential and electric conductance in internodal cells of Nitellopsis obtusa. Physiol. Plant. 70, 473-478 doi:10.1111/j.1399-3054.1987.tb02845.x

Stolarek J., Karcz W., Pietruszka M. (1988): Mathematical modelling of light-induced electric reaction of Cucurbita pepo L. leaves. Acta Soc. Bot. Pol. 57, 271-278

Tazawa M., Shimmen T. (2001): How characean cells have contributed to the progress of plant membrane biophysics. Aust. J. Plant Physiol. 28, 523-539

Tukaj Z., Baścik-Remisiewicz A., Skowroński T., Tukaj C. (2007): Cadmium effect on the growth, photosynthesis, ultrastructure and phytochelatin content of green microalga Scenedesmus armatus: A study at low and elevated $\mathrm{CO}_{2}$ concentration. Environ. Exp. Bot. 60, 291-299 doi:10.1016/j.envexpbot.2006.12.002

Verkleij J. A. C., Schat H. (1990): Mechanisms of metal tolerance in plants. In: Heavy Metal Tolerance in Plants: Evolutionary Aspects. (Ed. A. J. Shaw), pp. 179-193, CRC Press, Boca Raton

Received: June 24, 2010

Final version accepted: October 7, 2010 